\title{
PARTNERSHIP OPPORTUNITIES IN NEIGHBORHOOD TREE PLANTING INITIATIVES: BUILDING FROM LOCAL KNOWLEDGE
}

\author{
by Maureen E. Austin
}

\begin{abstract}
Tending to local residents, as well as the trees, in neighborhoods can have positive impacts on tree survivorship, community development, and improved relationships between foresters and the public. This study explored resident involvement in tree planting and maintenance projects on vacant lots in Detroit, Michigan, U.S. Thirty-eight individuals involved in follow-up care of tree planting sites were interviewed and surveyed to understand their motivations for involvement and their perception of these local neighborhood greening projects. Underlying motivations include an enjoyment from working with nature as well a strong social motivation. Recommendations are offered for forestry professionals seeking improved interactions with local constituents.
\end{abstract}

Key Words. Tree maintenance; community involvement; motivation.

Citizen tree planting projects are not only about getting trees into the ground. They also offer opportunities for forestry professionals to share their knowledge of tree selection, planting, and care with the public and to encourage resident involvement in forest stewardship. For local citizens, these projects provide not only a rapid transformation of their neighborhood but also the chance to learn about caring for trees. Residents soon find out that in addition to the trees, the planting site itself and the equipment also need care. In the process, the benefits extend far beyond the trees. A fuller appreciation of these dynamics could lead to better tree care, a more educated citizenry, and thriving communities.

The purpose of this paper is to share findings about resident involvement in tree planting projects on vacant lots in Detroit, Michigan, U.S., with a focus on the individuals most closely involved with the maintenance of these projects after the planting-day festivities are well past. What sustains their interest in these activities? What is their perspective on the vacant-lot projects and the role they play for the neighborhoods? Greater awareness of volunteer motivations, knowledge, and concerns can facilitate the interactions of forestry professionals with citizens, leading to increased understanding of how to involve local residents in future tree stewardship initiatives. Survivorship of neighborhood trees ultimately depends on local efforts supported and guided by professionals.

\section{MOVING BEYOND PLANTING DAY}

Planting days are busy, exciting, and active. Photo opportunities abound, because many people want to get in on the action. Planting days offer excitement to many neighborhoods that rarely experience this type of group activity. In addition, the end result can completely change the look of a neighborhood as only trees can. In just a few short hours, a residential block is transformed when street trees are added. Or an overgrown, vacant lot can go from an unsafe eyesore to a small pocket park filled with trees, flower beds, and mulched pathways.

Given all this fun and excitement, it is quite understandable that much attention is focused on planting day. Too much emphasis on tree planting, however, with limited attention to how the trees will be maintained afterward, may mean missing out on information that will be useful in directing future projects in other neighborhoods. Such information not only will improve efforts to encourage greater citizen involvement but may improve post-planting survival of trees by supporting local stewardship efforts.

\section{LITERATURE REVIEW}

City trees grow in a human environment. People play an important role in the nurture and care of city trees; people, however, also are the source of many predicaments affecting the trees' survival. It is thus hardly surprising that social, as well as environmental, concerns of an increasingly urbanized public have impacted the forestry profession. Both in the United States and abroad there has been increasing attention to human dimensions in crafting management plans. Sievert (1988) provides many creative examples of public relations campaigns designed to increase public awareness and support of local urban forest resources in Ohio cities and towns. The need to adapt the field to include even more 
consideration of the psychological and social values people place on trees was stressed early in the last decade (ISA 1991; Dwyer et al. 1991; Willeke 1994). Konijnendijk's (2000) study of urban forestry practices in European cities chronicles the changes the forestry profession has undergone in areas that have become increasingly urbanized.

To engage people in the care of city trees, it is useful first to know about their preferences and concerns. Sommer and Cecchettini (1992) found that asking citizen preference for tree planting location provided both a better understanding of citizen concerns as well as the opportunity for citizens to learn the importance of site parameters when choosing where to plant trees. A later study took this one step further by involving residents in the planting of neighborhood street trees (Sommer et al. 1994). Residents who planted and paid for their own street trees were more satisfied than those who didn't pay for or plant their trees. The work of Schroeder and Ruffolo (1996) offered an approach to tailor street tree planting programs to resident satisfaction with tree benefits. Their survey methodology allowed foresters to produce planting plans that function within existing management constraints while reflecting citizen preference for the visual benefits of street trees.

An appreciation of the public's preference and awareness of urban trees may be especially important when the appropriate action is to remove diseased or damaged trees. The heated exchanges characteristic of such situations are indicative of the strong attachment people have to trees. Their affection, however, generally is not matched by requisite knowledge. The need to remove trees thus provides a particularly salient opportunity for the forest professional to anticipate public concern. Munson (1993) shares an account of a public awareness and education campaign undertaken at Smith College in Massachusetts, when a historic American elm (Ulmus americana) needed to be removed. What could have been a fairly contentious situation instead became an example of highly successful public relations, allowing opportunities for citizens to understand the side of the profession dealing with the removal of diseased, dying, and hazard trees. Many of the benefits trees provide us are such an integral part of the cityscape that they often go unnoticed. It is only when they are removed (or about to be removed) that we recognize the values placed on these local resources. The loss of many trees in Charleston, South Carolina, from Hurricane Hugo provided clear evidence of citizens' fondness for trees. More than 30\% of those interviewed following the storm named urban forest features as the "most significant physical feature destroyed by hurricane" (Hull 1992).

\section{Volunteer Motivation}

Neighborhood tree planting initiatives present far more positive opportunities for forestry professionals to work closely with local citizens. Regardless of where these projects occur, accounts of planting day share similar details of the social and psychological benefits of citizen involvement in neighborhood tree planting initiatives (Sklar and Ames 1985; Lipkis and Lipkis 1990; Skelton 1994; Hynes 1996).

Neighborhood tree plantings are by no means the only opportunities for citizens to volunteer in urban forestry projects. Volunteers have been used successfully in conducting street tree inventories, in tree maintenance programs, and in ecosystem restoration projects. Bloniarz and Ryan (1996) found tree inventory data collected by volunteers to be reliable and the volunteer program a cost-effective approach for data collection. In addition, these volunteer programs offer additional benefits of increased citizen awareness, greater political support for urban tree programs, and an active role in neighborhood improvement.

Several studies have explored motivations of volunteers as a means for developing programs that encourage greater citizen involvement in local urban forest and ecological restoration programs. For example, Westphal's (1993) survey of Chicago's TreeKeepers volunteers found one of the top-ranked motivations for involvement was that the work "brings nature closer." She further found that motivations for involvement include "emotional, aesthetic, or spiritual values" more so than the many utilitarian benefits often extolled by the urban forestry profession as a whole. Still and Gerhold (1997), exploring motivations of urban forest volunteers in New York City and Philadelphia, discovered a desire to improve one's neighborhood proved to be the most important factor behind volunteer motivation. Grese et al. (2000) found social rewards to be one of the motivations but not the most important one. The cluster of items related to helping the environment was rated most strongly by their sample of volunteers involved in ecological restoration. Learning new things received the second-highest average rating. Hull and Gobster (2000) recommend learning about the underlying motivations of ecological restoration volunteers as a means for building a constituency. By encouraging the active involve- 
ment of local citizens in such ecological management efforts, the authors see possibilities for continued citizen education and increased responsibility for land management decisions. Continued exploration of why individuals participate in urban forest management initiatives can further efforts toward developing more inclusive and effective local stewardship efforts.

\section{Local Involvement and Local Knowledge}

Understanding urban forestry from the perspective of local residents - through the eyes of those closest to the trees-can forge effective partnerships between forestry professionals and the public. Carey (1998), of the Forest Trust in Santa Fe, New Mexico, relies on the knowledge of rural communities in developing management plans for local forest resources. Meskwaka, a tree planting organization that recruits local community activists and offers them training in return for a one-year commitment to serve, makes use of local knowledge and experience as trained volunteers then work within their own communities (Tenusak 1996). Notices of people having success with community participation in tree planting and maintenance activities build on the fact that local people know their local environment and community and care about this area in ways that outsiders never could. Learning more about the social dynamics of local tree planting projects can lead to greater opportunities to involve nearby residents.

\section{METHODS}

The study included 11 tree planting projects on cityowned vacant lots in Detroit neighborhoods. Unlike street tree plantings, these projects can be broad in scope, calling for considerable group involvement on planting day and afterward. Each of the projects entailed a partnership consisting of a local community organization, a nonprofit tree planting organization, and representatives from the city forestry department. Seven of the community organizations were concerned with neighborhood improvement and beautification, ranging in membership size from a single-block club to multiple blocks of residents. The remaining four organizations were nonprofit community service agencies serving a variety of local needs including community mental health, neighborhood housing, and shelter for the homeless. The planting sites were in neighborhoods throughout the city, representing a diverse geographical cross-section of Detroit.

Vacant lot tree planting projects often involve more than just trees. They provide opportunities for nearby residents to personalize the sites with shrubs, flowers, walkways, sitting areas, and other expressions of local interests. These once-vacant lots thus require all the usual attention for their new trees-watering, pruning, and yearly replenishment of mulch-as well as care and maintenance of their other plantings and special features. In addition, the lot will revert quickly to its former overgrown condition if it is not mowed regularly. These multiple components often translate into additional opportunities for resident involvement because individuals can apply their skills and talents in a variety of ways to keep the site as a viable part of the neighborhood scene. Follow-up visits to these sites afford forestry professionals a perspective of local stewardship often not available or considered in community tree planting programs.

Data were collected in three phases, with each phase focusing on a different group of residents involved in the planting project. Phase I involved neighborhood leaders-those individuals responsible for organizing the project. Phase II focused on maintenance workersthose residents involved in follow-up care of the completed project. Phase III surveyed residents living in proximity to completed vacant lot planting projects. Phase II results form the basis of this article.

Phase II of the data collection process included 38 residents involved in tending nine vacant-lot tree planting sites. Repeated efforts to make contact with maintenance workers responsible for care of the remaining two vacant lot projects included in other portions of the study proved unsuccessful. In many neighborhoods, local residents willingly participate in the upkeep of the lot project, doing so without compensation for their efforts and using their own equipment. Whenever possible, interviews took place on the project site and included all maintenance workers for that site. A semi-structured interview format was followed, and participants were asked to comment about specific tasks they performed, the frequency with which they worked, any difficulties they encountered, insights learned through participation in maintenance work, and their perceptions of project use by local residents. With the permission of the participants, interviews were tape recorded; interview tapes were then transcribed and interview data were content analyzed. The interview process generated a rich context of insights into citizen participation in local maintenance efforts. Maintenance worker quotes featured in this article (in italics) lend imagery to the overall findings.

In addition to the interview process, each maintenance worker completed a survey. The one-page survey included questions designed to measure motivations for participation in project care. Survey respondents were 
asked to rate the importance (on a 1 to 5 scale) of 14 psychological and social motivational items in their decision to care for the lot project. Typical psychological items included enjoyment from working with nature, feelings of relaxation and calm, and the desire to learn. Items measuring social motivation included helping one's neighborhood, creating something on behalf of the neighborhood, and a wish to become better acquainted with neighbors. Background demographic data also were obtained.

\section{RESULTS AND DISCUSSION Diversity of Involvement}

Vacant-lot planting projects are vastly different in size, shape, and existing natural features, so there is no predetermined model followed for the design of such a project. Instead, each project is shaped by professional input from the partnering entities (i.e., nonprofit tree planting organization and the city forestry department) according to site specifications and the goals of the community group. A project consisting of one lot containing grass and several deciduous and flowering trees, therefore, will require maintenance much different from a project consisting of several contiguous lots and containing mulched flower beds, wood chip or brick pathways, and shrub borders in addition to trees.

Maintenance workers were as diverse in their involvement patterns as the neighborhood vacant-lot projects. Some worked on their own, mowing the lots and tending the trees. Others participated as members of a neighborhood maintenance crew. In some neighborhoods, maintenance work was done on a weekly basis during the growing season. In other neighborhoods, participation was in the form of seasonal workdays designed to spruce up the lot rather than provide weekly upkeep. The participation of some individuals was dictated by their position as clients of a local community service agency. The majority of worker participation was voluntary; however, individuals involved in the maintenance of two projects received a small stipend for their services. Most residents participating in tree care used their own tools and equipment for the job.

Workers' ages also were diverse. One maintenance crew consisted entirely of neighborhood youth supervised by a neighborhood adult. In two other neighborhoods, teens participated in tree care alongside adults. Sixteen $(42 \%)$ of the workers were under age 19 . Half that many $(21 \%)$ were over 50 years of age, and the remaining $37 \%$ were between the ages 20 and 49 . The following synopses showcase the diversity of involve- ment patterns observed in maintaining these vacant lot planting efforts. (Note: Neighborhood organization names have been changed to respect privacy of the interview participants.)

Avalon Community Block Association. This northwest Detroit neighborhood has a youth crew assuming the maintenance responsibility for the local vacant-lot planting project. Those youth under age 18 participate by mulching and watering trees, picking up litter that blows into the lots, and sweeping sidewalks surrounding the lots. A riding mower is used to cut the grass; thus, this task is performed by youth aged 18 and older. In addition to maintaining the vacant lot where neighborhood residents have planted trees and shrubs, this crew participates in the beautification of several vacant lots in the neighborhood as well as a local city park. The group members, the majority of whom are African American, receive a small stipend for the hours they work each week. All work is performed under the watchful eye of an African American elder in the community. The neighborhood elder often quizzes her young charges about their work, referring to it as a "summer forestry program": "When we're doing our forestry, we are interested in planting. In forestry [program] we're taught. What did we plant last year? What's the name of those bushes over there? Who knows?"

East Side Neighborhood Block Club. On Detroit's east side, two African American men assume the responsibility for maintaining the vacant-lot planting project on their block. One man is retired and lives down the block; the other is a middle-aged laborer who lives across the street from the lot. Both men live close enough to keep a watchful eye on the project site and have been maintaining this lot since planting day, nearly three years prior to our interview. In addition to several shade and flowering trees planted there, the lot contains a shrub border, a winding brick pathway, wooden benches, and a colorful sign bearing the block club name. While the trees and shrubs received water on a weekly basis during the first two growing seasons, the majority of the lot care now involves weekly mowing and removal of paper that blows into the lot from time to time. Neighborhood children are drawn to the lot when the men are tending it: "Little bitty things, they little kids. They see us and they try to help."

Benson, Landau, and Martin Neighborhood Association. A sizeable vacant-lot planting project on the city's east side does not receive regular maintenance but rather is the target of an intensive spring clean-up 
every year by youth from a multicultural summer leadership program. The site is one of the organization's first neighborhood improvement projects, and program participants work on the lot for two weeks every year, in the process renewing old acquaintances and making new ones. The work they perform on the lot includes mowing the grass, mulching trees, painting lot borders, and removing litter. Past work has included building a sandbox and swing set, and planting a vegetable garden. One of the young participants shared a realization learned through her involvement: "Who would have known that you have anything in common with older people? Yet you do, and there you are working and talking together.You are then able to take that elsewhere. We were treated like we were grown-ups."

\section{Worker Motivation}

Of the 14 survey items workers were asked to rate regarding their motivations (Table 1), six received very high ratings $(\geq 4.0$ on a 1 -to- 5 scale). One of the three items receiving the highest mean (4.5) reflects their enjoyment from "working with nature." This finding is well reflected in a comment by one of the participants:

... sometimes I come out here and do it [watch birds].

You know, just to see the different kinds of birds that's over here [in the lot]. ...the mulberries are like the apples, they bring the birds, you know. The birds come in and eat the mulberries. The birds come in and you see the variety if you want to sit there and watch. Every once in a while you see a pheasant over there.

The two additional survey items sharing top endorsements in motivating worker involvement reflect a social component, underscoring the importance of community to local residents. These items include a desire to "help one's neighborhood" and "create something in the neighborhood." The quote below from an individual involved in project care reflects a strong community motivation to his participation in the work:

We even took care of the yard next door. We took care of that, you know, because that building is vacant. Right, so nobody's in there and it would make this [lot] look bad. See what I'm saying, if yours is neat and trim and that isn't, we would still take care of the yard next door, try to keep it, you know, we try to help the neighborhood look better.

Looking at the items receiving the lowest motivational averages for the workers is also informative. Because the majority of these workers participate in follow-up maintenance on a voluntary basis, "getting paid to maintain the lot" received a relatively low average score. The lowest-scoring item, "working there fills up my time," lends support to the notion that workers are not tending these lots out of boredom or a need to keep themselves busy.

Exploring the underlying motivations of local residents who choose to participate in follow-up care of tree planting projects can provide clues that will assist in enhancing local participation in future projects. A chance to work with nature is only one way to encourage local participation. Framing tree planting initiatives as a way to contribute to one's neighborhood or help one's community may enable forestry professionals to attract greater participation in local tree care initiatives.

Table 1. Motivations to participate in project maintenance.

\begin{tabular}{llc}
\hline "How important is each of the following in your decision to work on the lot?" & Mean* & Standard deviation \\
\hline Enjoy working with nature & 4.5 & .75 \\
Want to help my neighborhood & 4.5 & .82 \\
Chance to create something in neighborhood & 4.5 & .91 \\
Chance to give back to my community & 4.2 & 1.09 \\
Helps me get to know people in neighborhood & 4.0 & 1.18 \\
Gives me good exercise & 4.0 & 1.01 \\
Helped on planting day & 3.9 & 1.40 \\
Makes me feel relaxed and calm & 3.5 & 1.18 \\
No one else will do it & 3.3 & 1.60 \\
Want to learn how to take care of lot & 3.2 & 1.54 \\
Feel like the lot belongs to me & 3.1 & 1.30 \\
Was asked by a neighbor to help & 3.0 & 1.60 \\
Get paid to maintain lot & 2.8 & 1.81 \\
Working there fills up my time & 2.5 & 1.36
\end{tabular}

*Scale: $1=$ not at all; $3=$ some; $5=$ a great deal.

Paired samples t-test results indicate significant difference $(p<.05)$ between items at .5 scale level. 


\section{Local Knowledge}

Local residents tending tree planting projects have specific knowledge of their neighborhood useful to foresters such as what goes on there, how residents interact with one another, and how the completed project site is used by residents. In addition, through their work on the treed lots, these individuals have gained experience helpful in future neighborhood tree planting and maintenance efforts. During the interview process, maintenance workers spoke candidly and shared details about the steps taken to maintain their local vacant-lot planting project. The information they shared reflected the specifics of the maintenance work (including tree and lawn care) as well as their experience in tending these local neighborhood sites.

An overgrown vacant lot can visibly destroy the best intentions of local residents to keep their homes and yards looking neat and trim. Therefore, one of the main objectives of vacant-lot tree planting projects is beautification of the neighborhood. Often the planting project maintenance tasks requiring the greatest commitment of time and energy are mowing grass and picking up litter. Given the fact that many of these vacant lots were sites of illegal dumping and vandalism prior to their conversion to neighborhood oases, it was not surprising to hear maintenance workers describe these tasks with a great sense of purpose:

Pick up bits of paper around there and stuff like that, and you know just keep things nice and presentable, ... keep things looking nice ..., try to keep it orderly. Keep it clean mostly, that's the basics. You know, keep it cut and clean.

Mowing grass and picking up litter are not directly related to the maintenance of trees; however, regular maintenance of these lots is very important to the survival of the trees planted in them. Lots that do not receive regular mowing and litter removal soon revert to their previous overgrown condition. In addition, the continued follow-up maintenance by neighborhood residents alleviates the need for city mowing crews to enter these lots, thus keeping newly planted trees safe from the risks of mechanical damage inflicted by large machinery.

With mowing and litter under control, workers described additional tree care performed as part of their maintenance duties. Their work included watering newly planted trees, applying mulch, and pruning trees and trimming hedges. One worker reported trimming the trees on the lot "several times" while in another neighborhood workers said they had "trimmed hedges" as well. The yearly replenishment of mulch rings around these trees by maintenance workers is important in preventing mechanical damage. While workers in a northwest city neighborhood received wood chips every year from their district forestry department, workers from projects located in other parts of the city reported greater difficulties in obtaining wood chips on a regular basis.

Many workers stressed the need for an adequate number of people to assist with lot maintenance. The notion of involving others in the maintenance tasks was shared by those working in groups as well as individually:

You need a lot of people to take care of it, you know, looking after it, especially people from the neighborhood because they're around all the time.

Try to get volunteers to come at least once or twice a month to try to keep it clean and maintain it.

Many workers were eager to describe the difficulties encountered in keeping the lots maintained. They felt this information was important for future planting partners to know, giving them an increased awareness of the realities of tending a vacant-lot tree planting project. Lot-maintenance difficulties shared by workers included the large investment of time necessary and the need for water, tools, and equipment:

It's just a lot of hard work, that's all. It's just hard work. You just have to be dedicated. It's patience. It's not gonna happen like you want it the first year.You can't get discouraged.

The guy that lived there (across from the lot) used to help us water. He let us tap into his water supply, (but) then he moved.

We got in touch with our councilman to use the water from the hydrant over there, but it wasn't okayed. Water is very important. Our utilities, our water, frankly, has come from one of our neighbors. She volunteered but we paid her to use her water.

\section{Community Benefits}

Maintenance workers provide a local presence that is missing in projects tended by outside volunteers or forestry professionals. Familiar neighborhood faces working regularly to tend these tree sites reinforces the good feelings felt on planting day as neighbors gathered together to improve their neighborhood by planting trees. Drawing on the social ties that exist among neighborhood residents, the presence of local maintenance workers provides an incentive for encouraging others in the neighborhood 
to be involved. Workers were asked to share their feelings about local residents' perceptions of the vacant-lot project and the work performed on behalf of the neighborhood:

It's amazing; little kids want to help. Actually me and Dan are the two men role models on the block. I try to be and that gives me a lot of inspiration.

When we're out here cutting, everyone just slows up and looks. And the purpose of that community bulletin board is to get people's attention to what's going on here, you know, and they put their yard sale signs up there and that kind of thing, so it's starting to take off.

I think they notice it and I think they appreciate it. I do, too. Even though you got people who maybe don't care about it, nine times out of ten, I think they care about it.

It makes people come together to clean it up. I mean it makes this block come together.

When we return to work on the lot, the neighbors come out and participate. [This] lot is most owned by the neighbors, out of all the other lots that we've worked on.

\section{Implications for Urban Forestry Professionals}

Public education is an important aspect of the urban forestry profession. Interactions between forestry professionals and the public can be more positive through increased efforts to understand the urban audience. While citizen awareness of trees and the many benefits they provide is important, it is unlikely to be a sufficient goal when seeking increased involvement and stewardship on the part of local residents. Efforts to educate and involve neighborhood residents will be more effective if foresters approach educational and outreach programs with a greater understanding of how these residents view the neighborhood and what motivates their involvement in neighborhood improvement projects.

Planting projects that have the benefit of local neighborhood representation at the planning, planting, and maintenance stages have more opportunities for continued local involvement in the weeks and years after planting day. Local planting projects can provide multiple means for involving residents in stewardship efforts, and continued local participation provides additional opportunities for communication between foresters and their constituency. Highlighting the opportunities that urban tree planting projects offer residents to access na- ture, as well as to improve the neighborhood, allows forestry professionals to tap additional motivations and increase local involvement.

The involvement of local residents in these neighborhood tree planting projects on vacant lots has shown the positive effects of reaching other neighborhood residents. Local maintenance workers are familiar faces in the neighborhood and can provide additional access for residents who are reluctant to interact with municipal employees. Meanwhile, municipal foresters will find willing allies in these maintenance workers whose work is time-consuming and requires considerable input of energy and local resources. Opportunities abound for foresters to share their expertise with workers willing to learn new techniques and improve their effectiveness. In turn, these local residents can share a wealth of information about the neighborhood, local site conditions, and neighborhood concerns that are invaluable to ongoing urban reforestation efforts. The positive impacts maintenance workers have on others in the neighborhood can mean the difference between tree planting projects local residents feel ownership of and those that are seen simply as public property, often ignored or even defaced. By nurturing the relationship with local residents involved in project care, urban forest professionals can begin to understand and address the local concerns of their constituency.

Suggestions are offered to forestry professionals seeking a more rewarding interaction with local residents in tree planting projects.

Look, Listen, and Learn What Is Going on at the Neighborhood Level. Extend consideration of site characteristics beyond those of soil, microclimate, and existing infrastructure. Neighborhood social characteristics also factor heavily in the survivorship of urban trees. Observe the neighborhood, noting how residents interact in and around the proposed tree planting site. Ask questions of neighborhood leaders so that the project can be tailored to the strengths of the neighborhood as well as the neighborhood concerns. Understand the various ways residents interact with the site and with one another. Inquire who will be tending the trees in the weeks following planting day and directly involve these residents in the planning process.

Build on the Motivations of Current Maintenance Workers. The desire to help or improve one's neighborhood was rated equally as high as the motivation to work with nature. Neighborhood residents strongly motivated by community concerns may not initially recognize the social rewards of engaging in tree 
planting and care. By emphasizing opportunities tree planting projects offer for strengthening community social ties, foresters can encourage greater local participation in these efforts. Building on residents' ties to their community encourages the participation of those reluctant to partake due to a lack of tree care knowledge.

Target Follow-Up Care at the Neighborhood Level. Tree survival after planting day is largely based on proper follow-up care. The neighborhood and its residents also need attention after planting day. Schedule meetings with leaders and maintenance workers to determine which needs have arisen since planting day. Undoubtedly, questions surface as tree care evolves; therefore, a simple phone call may not only ensure tree survival but also can nurture the partnership between local residents and municipal foresters. Continue to support a working relationship with neighborhood planting partners, checking in, answering questions, and providing a presence in the neighborhood.

In addition to ensuring a long and healthy life of urban trees, attention to these details will encourage future projects of this type in these and nearby neighborhoods. Learn to see the neighborhood as well as the trees planted there. As neighborhoods flourish, so will the trees, strengthening the relationship between foresters and their constituents.

\section{LITERATURE CITED}

Bloniarz, D.V., and H.D.P. Ryan III. 1996. The use of volunteer initiatives in conducting urban forest resource inventories. J. Arboric. 22(2):75-82.

Carey, H. 1998. Living in balance with the land. Am. For. (Winter) 103:44-45.

Dwyer, J.F., H.W. Schroeder, and P.H. Gobster. 1991. The significance of urban trees and forests: Toward a deeper understanding of values. J. Arboric. 17(10):276-284.

Grese, R.E., R. Kaplan, R.L. Ryan, and J. Buxton. 2000. Psychological benefits of volunteering in stewardship programs, pp 265-280. In Gobster, P.H., and R. B. Hull (Eds.). Restoring Nature: Perspectives from the Social Sciences and Humanities. Island Press, Washington, DC.

Hull R.B. IV 1992. How the public values urban forests. J. Arboric. 18(2):98-101.

Hull, R.B., and P.H. Gobster. 2000. Restoring forest ecosystems: The human dimension. J. For. 98(8):32-36.

Hynes, H.P. 1996. A Patch of Eden: America's Inner-City Gardeners. Chelsea Green Publishing Co., White River Junction,VT. 185 pp.
International Society of Arboriculture. 1991. A National Research Agenda for Urban Forestry in the 1990s. ISA, Champaign, IL.

Konijnendijk, C.C. 2000. Adapting forestry to urban demands: Role of communication in urban forestry in Europe. Landscape Urban Plann. (52):89-100.

Lipkis, A., and K. Lipkis. 1990. The Simple Act of Planting a Tree. Jeremy P. Archer, Inc., Los Angeles, CA. 237 pp.

Munson, R.H. 1993. Handling the demise of historic trees: A problem of public relations. J. Arboric. 19(1):48-50.

Schroeder, H.W., and S.R. Ruffolo. 1996. Householder evaluations of street trees in a Chicago suburb. J. Arboric. 22(1):35-43.

Skelton, R. 1994. Harlem green-aissance. Amicus J. 16(3): 14-17.

Sklar, F., and R.G. Ames. 1985. Staying alive: Street tree survival in the inner-city. J. Urban Affairs. 7(1):55-65.

Sievert R.C. Jr. 1988. Public awareness and urban forestry in Ohio. J. Arboric. 14(2):48-51.

Sommer, R., and C. Cecchettini. 1992. Street tree location and sidewalk management preferences of urban householders. J. Arboric. 18(4):185-191.

Sommer, R., F. Learey, J. Summit, and M. Tirrell. 1994. The social benefits of resident involvement in tree planting. J. Arboric. 20(3):170-175.

Still, D.T., and H.D. Gerhold. 1997. Motivations and task preferences of urban forestry volunteers. J. Arboric. 23(3): 116-129.

Tenusak, K. 1996. Digging in. Am. For. (Summer) 102:29-32.

Westphal, L.M. 1993. Why Trees? Urban forestry volunteers values and motivations, pp 19-23. In Gobster, P.H. (Ed.). Managing Urban and High-Use Recreation Settings. USDA Forest Service, General Technical Report NC-163. North Central Forest Experiment Station, St. Paul, MN.

Willeke, D.C. 1994. Seeing around corners: Emerging issues in urban forestry. J. For. 92(10):16-18.

Acknowledgments. Funding for this research was provided by USDA Forest Service, North Central Forest Research Station, Co-op agreement 23-96-06. I wish to thank Rachel Kaplan for her thoughtful review of this paper, and I am also grateful for the helpful comments made by the anonymous reviewers.

Research Fellow

University of Michigan

School of Natural Resources and Environment

Dana Building, 430 E. University

Ann Arbor, MI 48109-1115, U.S. 
Résumé. Faire appel aux résidants du quartier peut avoir des effets positifs sur le taux de survie des arbres, sur le développement communautaire et aussi améliorer les relations entre les forestiers et le public. Cette étude explore l'implication des résidants dans la plantation d'arbres et leur entretien pour des projets sur des lots vacants de Detroit au Michigan. Trentehuit individus impliqués dans le suivi et l'entretien des sites de plantation d'arbres ont été interviewés et questionnés à propos de leurs motivations à s'impliquer ainsi que de leurs perceptions en regard de ces projets de reverdissement local de leur quartier. Les principales motivations incluaient un plaisir à travailler avec la nature tout comme une forte motivation sociale. Des recommandations sont offertes aux forestiers professionnels à la recherche d'interactions améliorées avec les groupes locaux.

Zusammenfassung. Die Aufmerksamkeit für Anwohner und ihre Bäume in der Nachbarschaft kann positive Auswirkungen auf die Überlebensrate, kommunale Entwicklung und verbesserte Beziehung zwischen Forstleuten und der Öffentlichkeit haben. Diese Studie untersucht die Einbeziehung von Anwohnern in Baumpflanzung und Pflegeprojekte auf freien Grundstücken in Detroit, Michigan. 38 Individuen, die in die nachfolgende Pflege von Baumstandorten einbezogen waren, wurden interviewt und Daten erhoben, um ihre Motivation für ihr Engagement zu verstehen und ihre Einschätzung dieser lokalen Begrünungsprojekte in ihrer Nachbarschaft zu erfahren. Die unterliegende Motivation beinhaltete eine Freude bei der Arbeit mit der Natur, sowie starke soziale Motivation. Die Empfehlung geht an die Forstleute, sich um bessere Beziehungen zu lokalen Einrichtungen und Leuten zu bemühen.

Resumen. La relación de los residentes locales con los árboles en los vecindarios puede tener impactos positivos en la supervivencia de los árboles, desarrollo de la comunidad y mejoramiento de las relaciones entre los forestales y el público. Este estudio explora a los residentes envueltos en proyectos de plantación y mantenimiento, en terrenos baldíos en Detroit, Michigan, U.S. Se entrevistaron a 38 personas implicadas en el cuidado de los árboles con el fin de entender sus motivaciones y su percepción de los proyectos locales de enverdecimiento. Las motivaciones incluyen un disfrute del trabajo con la naturaleza así como una fuerte conciencia social. Se ofrecen recomendaciones para mejorar las interacciones de los árboles con los actores locales. 